\title{
New genus-specific primers for PCR identification of Rubrobacter strains
}

\author{
Jean Franco Castro • Imen Nouioui · Juan A. Asenjo • Barbara Andrews • \\ Alan T. Bull $\cdot$ Michael Goodfellow
}

Received: 15 March 2019/Accepted: 1 August 2019/Published online: 12 August 2019

(C) The Author(s) 2019

\begin{abstract}
A set of oligonucleotide primers, Rubro223f and Rubro454r, were found to amplify a 267 nucleotide sequence of $16 \mathrm{~S}$ rRNA genes of Rubrobacter type strains. The primers distinguished members of this genus from other deeply-rooted actinobacterial lineages corresponding to the genera Conexibacter, Gaiella, Parviterribacter, Patulibacter, Solirubrobacter and Thermoleophilum of the class Thermoleophilia. Amplification of DNA bands of about 267 nucleotides were generated from
\end{abstract}

GenBank accession numbers: MK158160-75 for sequences from Salar de Tara and MK158176-92 for those from Quebrada Nacimiento.

Electronic supplementary material The online version of this article (https://doi.org/10.1007/s10482-019-01314-3) contains supplementary material, which is available to authorized users.

J. F. Castro · I. Nouioui · M. Goodfellow $(\bowtie)$

School of Natural and Environmental Sciences, Ridley

Building, Newcastle University,

Newcastle upon Tyne NE1 7RU, UK

e-mail:m.goodfellow@ncl.ac.uk

J. F. Castro · J. A. Asenjo - B. Andrews

Department of Chemical Engineering, Biotechnology and Materials, Centre for Biotechnology and Bioengineering (CeBiB), University of Chile, Beauchef 851, Santiago, Chile

\section{A. T. Bull}

School of Biosciences, University of Kent,

Canterbury, Kent CT2 1NJ, UK environmental DNA extracted from soil samples taken from two locations in the Atacama Desert. Sequencing of a DNA library prepared from the bands showed that all of the clones fell within the evolutionary radiation occupied by the genus Rubrobacter. Most of the clones were assigned to two lineages that were well separated from phyletic lines composed of Rubrobacter type strains. It can be concluded that primers Rubro223f and Rubro454r are specific for the genus Rubrobacter and can be used to detect the presence and abundance of members of this genus in the Atacama Desert and other biomes.

Keywords Actinobacteria $\cdot$ Rubrobacter Atacama desert · Taxonomy · Genus-specific primers

\section{Introduction}

The phylum Actinobacteria sensu Goodfellow (2012) contains several deeply branching lines of descent (Gao and Gupta 2012; Ludwig et al. 2012) including one composed of Rubrobacter species (Norman et al. 2017). Rubrobacter, the type and only genus in the family Rubrobacteraceae (Rainey et al. 1997; Zhi et al. 2009; Foesel et al. 2016) of the order Rubrobacterales (Rainey et al. 1997; Zhi et al. 2009; Foesel et al. 2016) of the class Rubrobacteria (Suzuki 2012a; Foesel et al. 2016) is loosely associated with taxa classified in the orders Gaiellales (Albuquerque et al. 
2011; Foesel et al. 2016), Solirubrobacterales (Reddy and Garcia-Pichel 2009; Foesel et al. 2016) and Thermoleophilales (Reddy and Garcia-Pichel 2009; Foesel et al. 2016), all of which belong to the class Thermoleophilia (Suzuki and Whitman 2012; Foesel et al. 2016). Albuquerque et al. (2011) assigned two mesophilic strains isolated from a mineral aquifer in Portugal to the genus Gaiella as Gaiella occulta; the genus was assigned to the family Gaiellaceae of the order Gaiellales. Similarly, the order Thermoleophilales of the class Thermoleophilia (Suzuki and Whitman 2012; Foesel et al. 2016) includes the family Thermoleophilaceae (Stackebrandt 2005; Zhi et al. 2009; Foesel et al. 2016) and the genus Thermoleophilum (Zarilla and Perry 1984) which contains two thermophilic species, Thermoleophilum album, the type species (Zarilla and Perry 1984) and Thermoleophilum minutum (Zarilla and Perry 1986). In turn, the order Solirubrobacterales encompasses four families of mainly soil bacteria, the Conexibacteraceae (Stackebrandt 2005; Zhi et al. 2009; Foesel et al. 2016), Parviterribacteraceae (Foesel et al. 2016), Patulibacteraceae (Takahashi et al. 2006; Foesel et al. 2016) and Solirubrobacteraceae (Stackebrandt 2005; Zhi et al. 2009; Foesel et al. 2016) and associated species, including the type strains Conexibacter woese $i$ (Monciardini et al. 2003), Parviterribacter kavangonensis (Foesel et al. 2016), Patulibacter minatonensis (Takahashi et al. 2006) and Solirubrobacter pauli (Singleton et al. 2003), respectively.

The genus Rubrobacter was proposed by Suzuki et al. (1988) to accommodate a $\gamma$-radiation resistant isolate from a hot spring in Japan and classified as Arthrobacter radiotolerans (Yoshinaka et al. 1973) prior to being renamed Rubrobacter radiotolerans. The genus description was emended by (Albuquerque et al. 2014). In general, Rubrobacter strains are obligately aerobic, Gram-stain positive, asporogenous, nonmotile actinobacteria which form irregular rods that occur singly, in pairs, tetrads and chains; the diamino-acid of the peptidoglycan is either L-lysine or meso-diaminopimelic acid; the predominant respiratory lipoquinone is MK-8, iso- and anteiso-fatty acids tend to prevail; their polar lipid patterns are complex, but usually include diphosphatidylglycerol and phosphatidylglycerol; and DNA G $+\mathrm{C}$ ratios fall within the range of 65-69 mol\% (Suzuki 2012b).

In addition to the type species, the genus currently contains eight species with validly published names,
Rubrobacter aplysinae isolated from the marine sponge Aplysina aerophoba (Kämpfer et al. 2014), Rubrobacter bracarensis from a deteriorated monument (Jurado et al. 2012; Albuquerque et al. 2014), Rubrobacter calidifluminis and Rubrobacter naiadicus from a fumarole heated stream in the Azores (Albuquerque et al. 2014), Rubrobacter indicoceani from a deep-sea sediment sample collected from the Indian Ocean (Chen et al. 2018), Rubrobacter spartanus from soil adjacent to the Kilauea volcanic caldera in Hawai (Norman et al. 2017), Rubrobacter taiwanensis from the Lu-Shan hot spring in Taiwan (Chen et al. 2004) and Rubrobacter xylanophilus from a thermally polluted effluent of a carpet factory in the United Kingdom (Carreto et al. 1996). The type strains of all but three of these species grow optimally at either 50 or $60^{\circ} \mathrm{C} ; R$. aplysinae grows optimally at $25^{\circ} \mathrm{C}$ and $R$. bracarensis and $R$. indicoceani at $28{ }^{\circ} \mathrm{C}$ (Jurado et al. 2012; Kämpfer et al. 2014; Chen et al. 2018). R. radiotolerans, $R$. taiwanensis and $R$. xylanophilus strains are remarkable for their resistance to high levels of $\gamma$ radiation (Yoshinaka et al. 1973; Ferreira et al. 1999; Chen et al. 2004), a property which may be conferred by stress genes, such as those involved in DNA repair homologous recombination, oxidative stress and compatible solute production (Egas et al. 2014).

Little is known about the ecology of Rubrobacter strains though they tend to be associated with extreme biomes, notably high temperature environments (Yoshinaka et al. 1973; Carreto et al. 1996; Ferreira et al. 1999; Chen et al. 2004; Albuquerque et al. 2014) while closely related strains have been isolated from Australian pasture soils (Janssen et al. 2002; Sait et al. 2002) and earthworm burrows (Furlong et al. 2002). In addition, culture-independent studies show that members of the genus Rubrobacter and closely related taxa are a feature of prokaryotic communities associated with rosy discoloured masonry and historic wall paintings (Schabereiter-Gurtner et al. 2001; Imperi et al. 2007), acid peat bog soil (Rheims et al. 1996), arid desert soils in Antarctica (de la Torre et al. 2003; Saul et al. 2005; Aislabie et al. 2006), Australia (Holmes et al. 2000; Janssen 2006) and Chile (Connon et al. 2007; Neilson et al. 2012; Crits-Christoph et al. 2013; DiRuggiero et al. 2013), heavy metal contaminated soils (Gremion et al. 2003; Moffett et al. 2003), as well as from Scottish grassland soils (McCaig et al. 1999) and earthworm burrows (Furlong et al. 2002). Holmes et al. (2000) designed an oligonucleotide 
probe, Rubro749, and used it to show that Rubrobacter and closely related taxa accounted for 2.6 and $10.2 \%$ of the bacterial flora of Australian Desert soils. These authors generated highly specific amplicons of Rubrobacter $16 \mathrm{~S}$ rRNA genes from community DNA extracted from a desert environmental sample using the oligonucleotide probe in tandem with the universal primer 27f (Lane 1991). It is important to evaluate the effectiveness of such oligonucleotide primers given the addition of new 16S rRNA gene sequences to curated databases.

In the present study, a pair of oligonucleotide primers was generated and shown to distinguish the type strains of Rubrobacter species from representatives of the other aforementioned genera deeply rooted in the actinobacterial 16S rRNA gene tree. The primers were also used in pilot experiments designed to determine the presence of Rubrobacter clones in environmental DNA extracted from Atacama Desert soils.

\section{Materials and methods}

Source and maintenance of the strains

The source and key properties of the type strains of five Rubrobacter species and corresponding Conexibacter, Patulibacter, Solirubrobacter and Thermoleophilum strains are shown in Table 1, together with media used to cultivate them. All of the strains were maintained as slants on the appropriate agar media at room temperature and as $20 \%$ glycerol stocks at $-80{ }^{\circ} \mathrm{C}$.

\section{Environmental samples}

Four environmental samples were taken to represent different Atacama Desert habitats as shown in Table 2.

Nucleotide sequences and bioinformatic analyses

16S rRNA gene sequences of the type strains of species classified in the genera shown in Table 1 were retrieved from GenBank (Benson et al. 2005) as were those of type strains of additional Conexibacter, Patulibacter, Rubrobacter and Thermoleophilum strains and of those of Gaiella and Parviterribacter species, as shown in Table S1. The corresponding sequence of Escherichia coli strain K-12 sub-strain MG1655 was accessed by its EcoGene number EG30084. Nucleotide alignments designed to identify conserved regions in Rubrobacter 16S rRNA genes were sought with the Clustal Omega (Sievers et al. 2011) webserver (https://www.ebi.ac.uk/Tools/msa/ clustalo/) leaving the parameters in default mode. Nucleotide alignments were visualised in Jalview version 2 (Waterhouse et al. 2009); the position of nucleotides in the alignments followed E. coli $16 \mathrm{~S}$ rRNA gene sequence numbering (Brosius et al. 1978; Yarza et al. 2014). In silico assessment of the specificity of the primers designed for the genus Rubrobacter was performed with the tool Probe Match available from the Ribosomal Database Project (RDP) server (https://rdp.cme.msu.edu/probematch/search. jsp) release 11 version 5 , which has a repository of sequences of 16S rRNA genes of thousands of cultivable and non-cultivable bacteria (Cole et al. 2014). Additionally, the specificity of the primers was evaluated with Primer-BLAST software (https://www. ncbi.nlm.nih.gov/tools/primer-blast/) from the National Center for Biotechnology Information (NCBI) against a non-redundant database and default parameters (Ye et al. 2012).

DNA extraction, PCR amplification and DNA fragment library construction

Genomic DNA was extracted from the strains shown in Table 1 using biomass grown for 10 days on the appropriate growth media at optimal temperatures. Biomass scraped from the surface of each of the agar plates, using sterile bacteriological loops, was washed twice in sterile water, resuspended in $0.5 \mathrm{ml}$ of sterile distilled water and homogenised using micropestles. The extraction of genomic DNA was performed after Kieser et al. (2000). In turn, the extraction of environmental DNA from the environmental samples was achieved using a PowerSoil ${ }^{\circledR}$ DNA Isolation Kit (MO BIO, Cat. No. 12888). Polymerase chain reactions (PCR) were carried out with Phusion HighFidelity DNA polymerase (Thermo) using the GC buffer with $3 \%$ dimethyl sulfoxide following the manufacturer's conditions. Ten ng of genomic DNA from the reference strains was used for the PCR amplifications under the following conditions: $98{ }^{\circ} \mathrm{C}$ for 2 min (initial denaturation); 30 cycles of $98^{\circ} \mathrm{C}$ for 
Table 1 Type strains of Rubrobacter species and those of related genera, their growth requirements and 16S rRNA gene sequence accession numbers

\begin{tabular}{|c|c|c|c|c|c|}
\hline Strains & Source & Growth media & $\begin{array}{l}\text { Optimal } \\
\text { growth } \\
\text { temperatures } \\
\left({ }^{\circ} \mathrm{C}\right)\end{array}$ & $\begin{array}{l}\text { 16S rRNA gene } \\
\text { sequence } \\
\text { accession } \\
\text { numbers }\end{array}$ & References \\
\hline Rubrobacter aplysinae & DSM $27440^{\mathrm{T}}$ & $\begin{array}{c}\text { DSMZ medium No. } \\
514+1 \% \text { starch }\end{array}$ & 25 & GU318365 & $\begin{array}{l}\text { Kämpfer et al. } \\
\text { (2014) }\end{array}$ \\
\hline Rubrobacter bracarensis & DSM $24908^{T}$ & DSMZ medium No. 1350 & 28 & EU512991 & $\begin{array}{l}\text { Jurado et al. } \\
\text { (2012) }\end{array}$ \\
\hline Rubrobacter calidifluminis & JCM $19154^{\mathrm{T}}$ & JCM medium No. 49 & 60 & KF494338 & $\begin{array}{l}\text { Albuquerque } \\
\text { et al. (2014) }\end{array}$ \\
\hline Rubrobacter naiadicus & JCM $19155^{\mathrm{T}}$ & JCM medium No. 49 & 60 & KF494339 & $\begin{array}{l}\text { Albuquerque } \\
\text { et al. (2014) }\end{array}$ \\
\hline Rubrobacter radiotolerans & $\mathrm{JCM} 2153^{\mathrm{T}}$ & JCM medium No. 49 & 37 & X87134 & $\begin{array}{l}\text { Suzuki et al. } \\
\text { (1988) }\end{array}$ \\
\hline Rubrobacter taiwanensis & JCM $12932^{\mathrm{T}}$ & JCM medium No. 49 & 55 & AF465803 & Chen et al. (2004) \\
\hline Rubrobacter xylanophilus & JCM $11954^{\mathrm{T}}$ & JCM medium No. 48 & 60 & CP000386 & $\begin{array}{l}\text { Carreto et al. } \\
\text { (1996) }\end{array}$ \\
\hline Conexibacter arvalis & DSM $23288^{\mathrm{T}}$ & DSMZ medium No. 92 & 28 & AB597950 & Seki et al. (2012) \\
\hline Conexibacter woesei & JCM $11494^{\mathrm{T}}$ & JCM medium No. 245 & 28 & CP001854 & $\begin{array}{l}\text { Monciardini et al. } \\
\text { (2003) }\end{array}$ \\
\hline Patulibacter americanus & $\mathrm{JCM} 16550^{\mathrm{T}}$ & JCM medium No. 26 & 25 & ATUD01000029 & $\begin{array}{l}\text { Reddy and } \\
\text { Garcia-Pichel } \\
\text { (2009) }\end{array}$ \\
\hline Patulibacter ginsengiterrae & DSM $25990^{\mathrm{T}}$ & DSMZ medium No. 830 & 25 & EU710748 & Kim et al. (2012) \\
\hline $\begin{array}{l}\text { Patulibacter } \\
\quad \text { medicamentivorans }\end{array}$ & DSM $25962^{\mathrm{T}}$ & DSMZ medium No. 830 & 28 & AGUD01000068 & $\begin{array}{l}\text { Almeida et al. } \\
(2013)\end{array}$ \\
\hline Patulibacter minatonensis & NCIMB $14347^{\mathrm{T}}$ & NCIMB medium No. 283 & 26 & AB193261 & $\begin{array}{l}\text { Takahashi et al. } \\
\text { (2006) }\end{array}$ \\
\hline $\begin{array}{l}\text { Solirubrobacter } \\
\text { ginsenosidimutans }\end{array}$ & JCM $19086^{\mathrm{T}}$ & JCM medium No. 346 & 28 & EU332825 & An et al. (2011) \\
\hline Solirubrobacter pauli & $\mathrm{JCM} 13025^{\mathrm{T}}$ & JCM medium No. 26 & 28 & AY039806 & $\begin{array}{l}\text { Singleton et al. } \\
(2003)\end{array}$ \\
\hline Solirubrobacter phytolaccae & $\mathrm{JCM} 31078^{\mathrm{T}}$ & JCM medium No. 346 & 28 & KF459924 & Wei et al. (2014) \\
\hline Solirubrobacter soli & JCM $14923^{\mathrm{T}}$ & JCM medium No. 346 & 28 & AB245334 & Kim et al. (2007) \\
\hline Solirubrobacter taibaiensis & $\mathrm{JCM} 31079^{\mathrm{T}}$ & JCM medium No. 346 & 28 & KF551107 & $\begin{array}{l}\text { Zhang et al. } \\
\text { (2014) }\end{array}$ \\
\hline
\end{tabular}

Type strains of the type species of genera are given in bold

DSMZ Deutsche Sammlung von Mikroorganismen und Zellkulturen, KCTC Korean collection for type cultures, JCM Japan collection of microorganisms, $N C I M B$ natural collection of industrial and marine bacteria

$30 \mathrm{~s}$ (denaturation), $58{ }^{\circ} \mathrm{C}$ for $30 \mathrm{~s}$ (annealing) and $72{ }^{\circ} \mathrm{C}$ for $3 \mathrm{~s}$ (extension); $72{ }^{\circ} \mathrm{C}$ for $2 \mathrm{~min}$ (final extension); the annealing temperatures and the extension times were set after checking different values for these parameters. The resulting fragments were purified after electrophoresis in agarose gels using a
GeneJET Gel Extraction Kit (Thermo Scientific, cat. No. K0691) and sent for sequencing to Macrogen Inc. (South Korea).

PCR amplicons obtained from the environmental DNA samples were purified from the agarose gels and cloned into plasmid pJET1.2/blunt using a CloneJET 
Table 2 Locations of environmental samples collected from diverse Atacama Desert habitats

\begin{tabular}{|c|c|c|c|c|c|c|}
\hline $\begin{array}{l}\text { Sampling site and } \\
\text { code }\end{array}$ & Description of samples & $\begin{array}{l}\text { Collection } \\
\text { date }\end{array}$ & Latitude & Longitude & $\begin{array}{l}\text { Altitude } \\
\text { (m.a.s.1.) }\end{array}$ & $\begin{array}{l}\text { Amplicons } \\
\text { generated }\end{array}$ \\
\hline $\begin{array}{l}\text { Aguas Calientes } \\
\text { (AC) }\end{array}$ & $\begin{array}{l}\text { Halite encrusted soil from the edge of } \\
\text { Salar de Atacama }\end{array}$ & 04.11 .16 & $23^{\circ} 08^{\prime} 79^{\prime \prime} \mathrm{S}$ & $67^{\circ} 25^{\prime} 29^{\prime \prime} \mathrm{W}$ & 4167 & No \\
\hline $\begin{array}{l}\text { Quebrada } \\
\text { Nacimiento } \\
(\mathrm{QN})\end{array}$ & Sand near vegetation & 04.12 .17 & $23^{\circ} 37^{\prime} 06^{\prime \prime} \mathrm{S}$ & $67^{\circ} 50^{\prime} 56^{\prime \prime} \mathrm{W}$ & 3646 & Yes \\
\hline $\begin{array}{l}\text { Salar de Tara } \\
\quad \text { (ST1) }\end{array}$ & Sand taken from under rock & 06.11 .16 & $23^{\circ} 02^{\prime} 97^{\prime \prime} \mathrm{S}$ & $67^{\circ} 18^{\prime} 87^{\prime \prime} \mathrm{W}$ & 4366 & Yes \\
\hline $\begin{array}{l}\text { Valle de la Luna } \\
\text { (VL) }\end{array}$ & Halite encrusted soil & 04.11 .16 & $22^{\circ} 55^{\prime} 08^{\prime \prime} \mathrm{S}$ & $68^{\circ} 19^{\prime} 20^{\prime \prime} \mathrm{W}$ & 2507 & No \\
\hline
\end{tabular}

PCR Cloning Kit (Thermo Scientific, cat. No. K1231) following the manufacturer's instructions. Transformations were carried out using E. coli DH5 $\alpha$ as host and carbenicillin $50 \mu \mathrm{g} / \mathrm{ml}$ as the selective marker on Luria-Bertani agar (Difco). Positive clones were chosen by colony-PCR using Phusion High-Fidelity DNA polymerase and the forward primer pJET1.2 (5'CGACTCACTATAGGGAGAGCGGC- $3^{\prime}$ ) and the reverse primer pJET1.2 (5'-AAGAACATCGATT TTCCATGGCAG- $3^{\prime}$ ) and grown overnight in $10 \mathrm{ml}$ Luria-Bertani broth supplemented with $50 \mu \mathrm{g} / \mathrm{ml}$ carbenicilin for plasmid DNA extraction with a GeneJET $^{\mathrm{TM}}$ Plasmid Miniprep Kit (Thermo Scientific, cat. No. K0502). This library of clones was sequenced using the pJET1.2 forward primer from Macrogen. The quality of the sequences were analysed using the Staden package (Staden et al. 2000) and the backbone vector sequence manually removed to obtain the final sequence fragments of the 16S rRNA genes amplified with the specific primers using the environmental DNA samples. Duplicated 16S rRNA gene sequences were identified using the ElimDupes tool from the HIV sequence database (https://www.hiv.lanl.gov/co ntent/sequence/elimdupesv2/elimdupes.html).

Phylogenetic analyses

The taxonomic affiliation of the 16S rRNA gene fragments obtained from the PCR runs with the designed primers were assessed in the EzBioCloud server (https://www.ezbiocloud.net) (Yoon et al. 2017) using the tool Identify. Phylogenetic trees were generated using the Genome-to-Genome Distance Calculator (GGDC; http://ggdc.dsmz.de/ggdc.php\#) webserver (Meier-Kolthoff et al. 2013); visualised in
FigTree version 1.4.2 (http://tree.bio.ed.ac.uk/ software/figtree/).

\section{Results and discussion}

Design of genus-specific primers

Conserved nucleotide signatures were sought in the 16S rRNA genes of the Rubrobacter type strains based on nucleotide alignments of $16 \mathrm{~S}$ rRNA gene sequences and corresponding sequences of the type strains of species assigned to genera classified in the class Thermoleophilia (Fig. 1).

The DNA regions found to be specific to the $16 \mathrm{~S}$ rRNA genes of the Rubrobacter strains were used as the starting point for primer design with unique $3^{\prime}$ ends for both forward and reverse primers. The first conserved region was $5^{\prime}$-GCG- $3^{\prime}$ in positions $221-223$ (E. coli numbering) and the second comprised $5^{\prime}$ GGCGAA-3' in positions 454-460. These conserved regions were used to design a pair of primers for the amplification of a 267 nucleotide region within the range 223 to 454 of the $16 \mathrm{~S}$ rRNA genes. The forward primer, Rubro223f (5'-AGCTTCGGCCATCCGG CG- $\left.3^{\prime}\right)$ and the reverse primer, Rubro454r (5'-GG GCTATTAACCCTTCGCC- $3^{\prime}$ ) consisted of 18 and 19 nucleotides, respectively.

The specificity of primers Rubro223f and Rubro454r was evaluated in silico using the RDP webserver (Cole et al. 2014) both individually and as a pair (Table 3). When tested, each primer was highly specific in detecting the 16S rRNA gene sequences of the Rubrobacter strains. In turn, when tested together, the specificity was above $98 \%$. Additionally, 


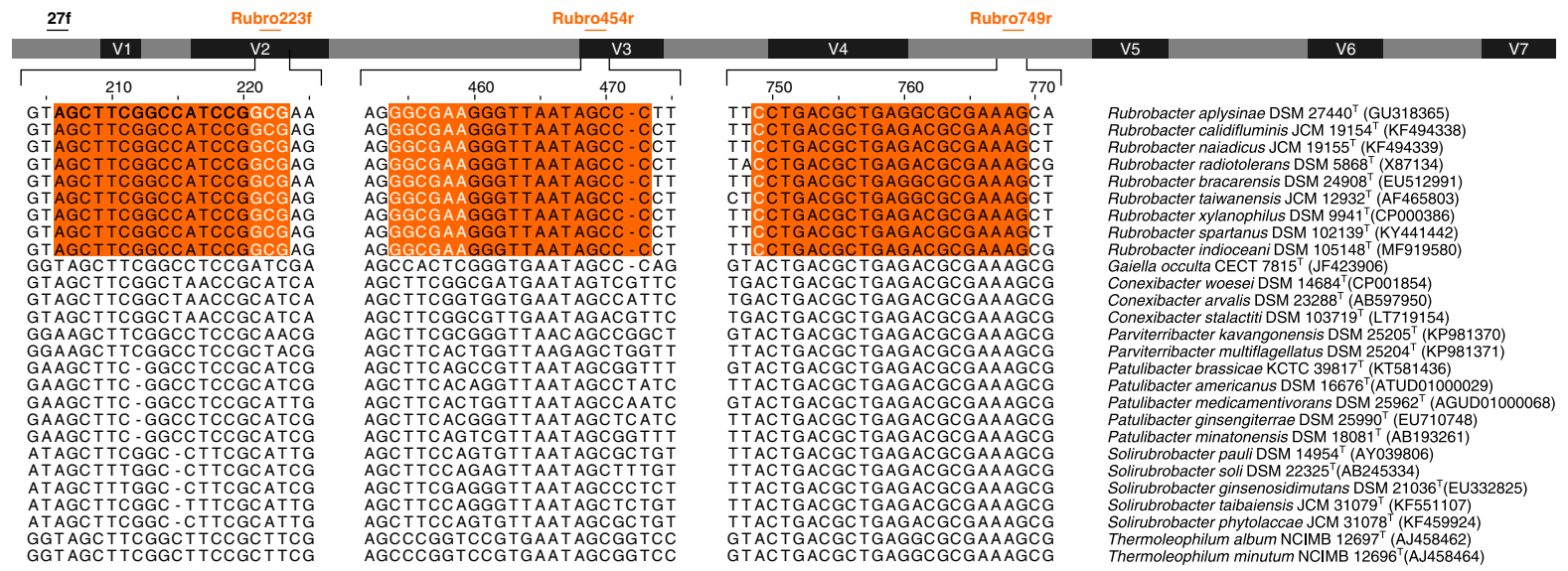

Fig. 1 Conserved nucleotide regions of 16S rRNA genes of Rubrobacter type strains used to design the specific primers Rubro223f and Rubro454r. The bar represents the 16S rRNA gene sequence of Escherichia coli; black boxes indicate conserved regions and the grey ones variable regions (V) with corresponding numbers (Brosius et al. 1978; Yarza et al. 2014). Arrows above the bar represent the position of the primers within the 16S rRNA gene sequence. Nucleotide alignment for primers Rubro223f and Rubro454r and for primer Rubro749r (Holmes et al. 2000) are highlighted in orange boxes and nucleotides in white represent those unique to the genus Rubrobacter and hence absent in the type strains of species classified in the genera Conexibacter, Gaiella, Parviterribacter, Patulibacter, Solirubrobacter and Thermoleophilum. (Color figure online) electronic PCR (Ye et al. 2012) underlined the high specificity of the primers, as $99 \%$ of the hits corresponded to representatives of the genus Rubrobacter (Tables 1 and S2). Consequently, primers Rubro223f and Rubro454r were synthesised and used to validate in vitro PCR with genomic DNA extracted from the type strains shown in Table 1.

\section{Validation of the primers with genomic DNA}

The primer set Rubro223f and Rubro454r was used to amplify the 267 nucleotide region of genomic DNA extracted from seven Rubrobacter type strains and from corresponding representatives of the closely related genera, as cited in Table 1 . The primers enabled specific amplification of a region of the expected size from the genomes of the Rubrobacter strains (Fig. 2). Sequencing of these DNA fragments matched with corresponding sequences derived from the respective Rubrobacter strains. Consequently, it can be concluded that the primers specifically amplify a $267 \mathrm{nt}$ fragment of the Rubrobacter type strains even though the region of genomic DNA amplified is short. These genus specific primers allow Rubrobacter strains to be distinguished from type strains of species assigned to genera classified in the class Thermoleophilia (Fig. S1).

Use of the genus specific primers to detect Rubrobacter strains in selected Atacama Desert soils

Primers Rubro223f and Rubro454r were used to amplify community DNA extracted from environmental samples taken from four diverse habitats in the Atacama Desert; bands were obtained for the Salar de

Table 3 Assessment of the specificity of primers Rubro223f and Rubro454r using the RDP database

\begin{tabular}{|c|c|c|c|c|c|}
\hline \multicolumn{2}{|l|}{ Rubro223f } & \multicolumn{2}{|l|}{ Rubro454r } & \multicolumn{2}{|c|}{ Rubro223f/Rubro454r } \\
\hline Actinobacteria & Rubrobacter & Actinobacteria & Rubrobacter & Actinobacteria & Rubrobacter \\
\hline 1049 & $1035(98 \%)^{\mathrm{a}}$ & 1058 & $1038(98 \%)$ & 717 & $717(99 \%)^{\mathrm{a}}$ \\
\hline
\end{tabular}

${ }^{\mathrm{a}}$ The hits are based on Rubrobacter strains deposited in the RDP database, apart from those of R. spatanus and $R$. indicoceani which were not available 
Fig. 2 Verification of the specificity of primers Rubro223f and Rubro454r in PCR runs using genomic DNA extracted from Rubrobacter type strains and corresponding strains of the closely-related genera. Electrophoresis in 2\% agarose gels shows PCR amplification of a region of $267 \mathrm{nt}$ that was only found in the Rubrobacter strains

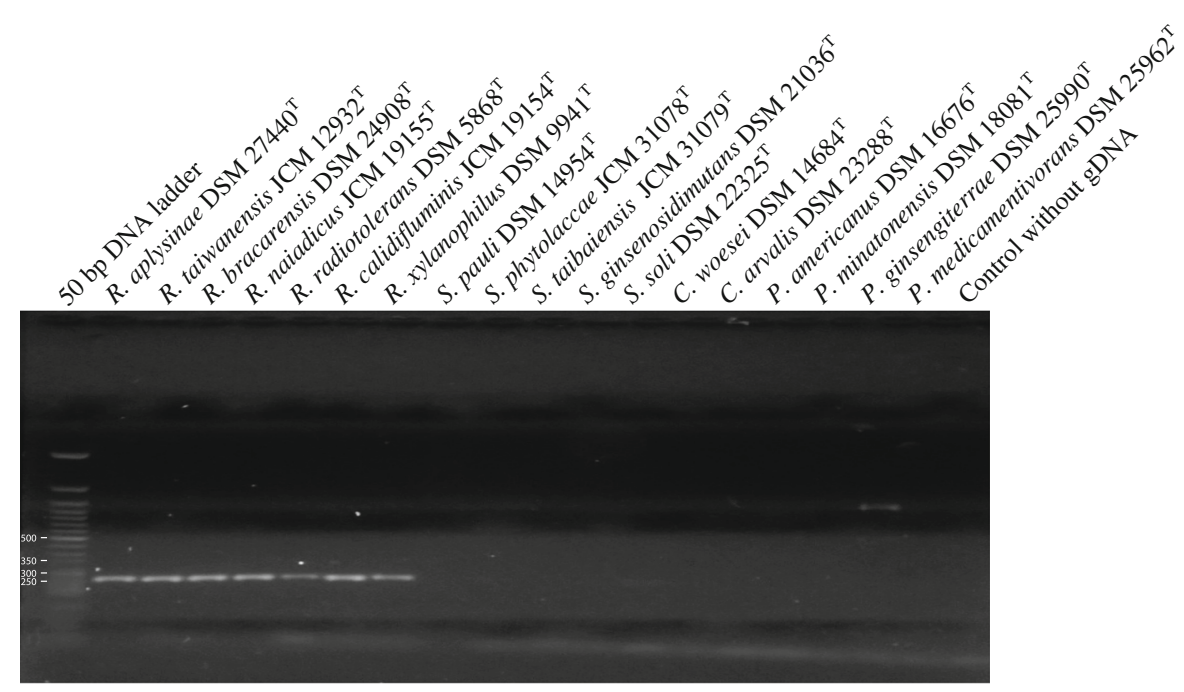

Tara (ST1) and Quebrada Nacimiento (QN) samples (Table 2). The purified amplicons were used to generate DNA libraries; 32 clones from sample QN and 37 from ST1 were selected and sequenced. The results from each of the sequences submitted to EzBioCloud (Yoon et al. 2017) showed that all of them corresponded to the genus specific fragment of the $16 \mathrm{~S}$ rRNA gene characteristic of members of the genus Rubrobacter. Seventeen out of the 32 clones from sample QN represented unique clones; the corresponding figures from the ST1 sample were 16 unique sequences out of 37 clones. These results provide further evidence of the specificity of the primers. Future research is required to determine the adaptive mechanisms that have evolved in Rubrobacter strains to enable their survival in the harsh environmental conditions that prevail in the Atacama Desert.

Phylogeny based on 16S rRNA gene fragments

The 16S rRNA gene sequences of the clones generated from the PCR analyses of the community DNA were compared with corresponding sequences of the type strains of Rubrobacter species and those representing the genera Conexibacter, Gaiella, Parviterribacter, Patulibacter, Solirubrobacter and Thermoleophilum. It can be seen from Fig. 3 that all of the clones were recovered within the evolutionary radiation occupied by the genus Rubrobacter, an association supported by a $100 \%$ bootstrap value based on the maximumlikelihood and maximum-parsimony analyses. In contrast, the type strains of the other genera formed a second well defined clade. The type strains of Conexibacter, Patulibacter and Thermoleophilum also formed lineages supported by high bootstrap values that ranged from 66 to $100 \%$ (Fig. 3). It is also evident from the maximum-likelihood tree based on the $267 \mathrm{nt}$ sequences of the type strains of all seven genera that the Rubrobacter strains fall into a distinct clade, as do those of the other six genera (Fig. S1). These welldefined taxa correspond to the classes Rubrobacteria (Suzuki 2012a) and Thermoleophilia (Albuquerque et al. 2011; Suzuki and Whitman 2012; Foesel et al. 2016).

Twenty out of the 33 clones (61\%) were recovered in two lineages that were sharply separated from the Rubrobacter type strains (Fig. 3). The first taxon, which was supported by very high bootstrap values, encompassed 18 clones, 12 from QN and 6 from ST, while the second one contained two clones from the QN. In turn, clones QN14, QN15 and ST9 formed a well-supported phyletic line together with the type strains of $R$. aplysinae, $R$. bracarensis, $R$. indicoceani and $R$. radiotolerans, the type species of the genus; the final clone, ST15 was loosely associated with this lineage. These results provide further evidence that Atacama Desert soils are likely to be a rich source of novel Rubrobacter species (Connon et al. 2007; Neilson et al. 2012; Crits-Christoph et al. 2013; DiRuggiero et al. 2013).

It can be concluded that primers Rubro223f and Rubro454r are effective in distinguishing Rubrobacter strains from related actinobacterial genera classified in the class Thermoleophilia and in detecting the 


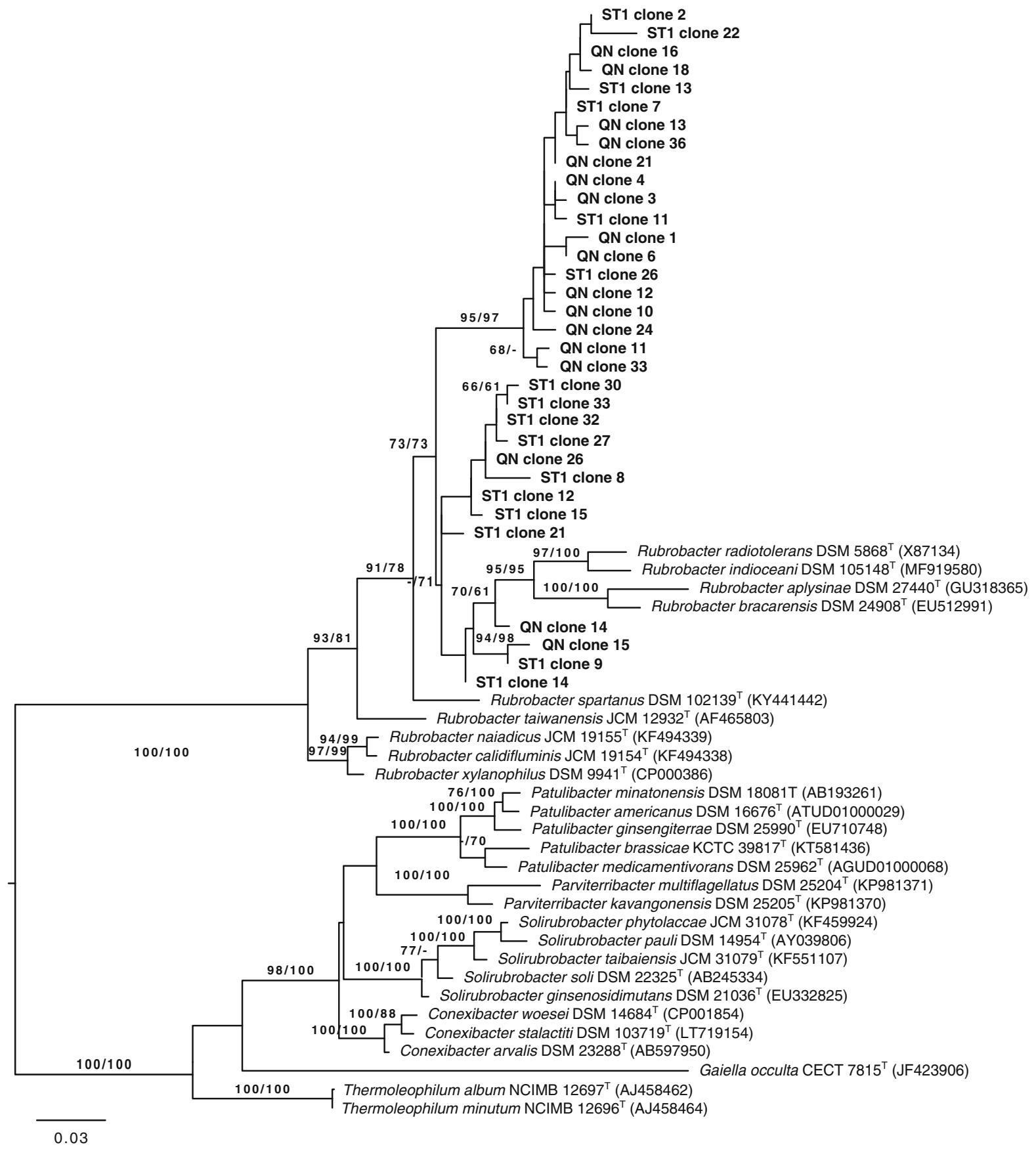

Fig. 3 Maximum-likelihood phylogenetic tree generated using the GTR + CAT model and rooted by midpoint-rooting showing relationships between the $267 \mathrm{nt}$ sequences amplified with primers Rubro223f and Rubro454r, using community DNA extracted from Salar de Tara (ST1) and Quebrada Nacimiento (QN) soils and the corresponding full 16S rRNA gene sequences of the type strains of representatives of the genera Conexibacter, Gaiella, Parviterribacter, Patulibacter, Solirubrobacter and Thermoleophilum. The branches of the tree are scaled in terms of the expected number of substitutions per site and the numbers above the branches are bootstrap support values greater than $60 \%$ for the ML (left) and MP (right) analyses 
presence and abundance of 16S rRNA gene clones in Atacama Desert soils. They are also likely to be useful for detection of Rubrobacter strains in other natural habitats, as well as identifying colonies of Rubrobacter growing on isolation plates incubated at 28 and $50{ }^{\circ} \mathrm{C}$ (Carreto et al. 1996; Chen et al. 2004; Jurado et al. 2012), thereby providing a lead for bioprospecting, ecological and physiological studies on members of this poorly studied taxon. Such investigations are needed as it has been shown that culture based procedures grossly underestimate the extent of novel actinobacterial diversity within the Atacama Desert landscape (Idris et al. 2017; Bull et al. 2018) and in marine sediments (Stach et al. 2003).

It is also clear that new procedures are needed to cultivate members of Rubrobacter communities known to be present in natural bioemes, especially at a time when the ability to generate metagenomic data far outstrips the capacity to cultivate microorganisms as highlighted by Goodfellow et al. (2018), which also outlines promising new strategies for bringing previously uncultured bacteria into culture.

Acknowledgements BA, JAA, JFC, ATB and MG are grateful for support from the UK Newton Project for UKChile collaboration (grant JIC CA586). BA, JAA and JFC are indebted to CONICYT (Chile) for funding of the Centre for Biotechnology and Bioengineering, $\mathrm{CeBiB}$ (project FB0001). IN thanks Newcastle University for a postdoctoral fellowship and ATB and MG are indebted to the Leverhulme Trust for Emeritus Fellowships. Thanks are also due to Valeria Razmilic (Centre for Biotechnology and Bioengineering, University of Chile) for her help in collecting soil samples from Quebrada Nacimiento; the remaining samples were collected by ATB and MG. We thank Steve Schmidt (Department of Ecology and Evolutionary Biology, University of Colorado, Boulder, CO) for discussions that prompted this study following his group's discovery of large populations of rubrobacteria in high elevation sites in the Central Andes.

Authors' contributions JFC and MG conceived of the project. JFC was responsible for the experimental work, IN for some of the computing and BA and JA obtained permission to collect soil samples from colleagues at the University of Antofagasta. JFC and MG drafted the manuscript which was critically reviewed by all of the authors.

\section{Compliance with ethical standards}

Conflict of interest The authors declare that they have no conflict of interest.

Human and animal rights This article does not include any studies involving human participants or animals.
Open Access This article is distributed under the terms of the Creative Commons Attribution 4.0 International License (http:// creativecommons.org/licenses/by/4.0/), which permits unrestricted use, distribution, and reproduction in any medium, provided you give appropriate credit to the original author(s) and the source, provide a link to the Creative Commons license, and indicate if changes were made.

\section{References}

Aislabie JM, Chhour K-L, Saul DJ, Miyauchi S, Ayton J, Paetzold RF, Balks MR (2006) Dominant bacteria in soils of Marble Point and Wright Valley, Victoria Land, Antarctica. Soil Biol Biochem 38:3041-3056. https://doi. org/10.1016/j.soilbio.2006.02.018

Albuquerque L, Franca L, Rainey FA, Schumann P, Nobre MF, da Costa MS (2011) Gaiella occulta gen. nov., sp. nov., a novel representative of a deep branching phylogenetic lineage within the class Actinobacteria and proposal of Gaiellaceae fam. nov. and Gaiellales ord. nov. Syst Appl Microbiol 34:595-599. https://doi.org/10.1016/j.syapm. 2011.07.001

Albuquerque L, Johnson MM, Schumann P, Rainey FA, da Costa MS (2014) Description of two new thermophilic species of the genus Rubrobacter, Rubrobacter calidifluminis sp. nov. and Rubrobacter naiadicus sp. nov., and emended description of the genus Rubrobacter and the species Rubrobacter bracarensis. Syst Appl Microbiol 37:235-243. https://doi.org/10.1016/j.syapm.2014.03.001

Almeida B, Vaz-Moreira I, Schumann P, Nunes OC, Carvalho G, Crespo MTB (2013) Patulibacter medicamentivorans sp. nov., isolated from activated sludge of a wastewater treatment plant. Int J Syst Evol Microbiol 63:2588-2593. https://doi.org/10.1099/ijs.0.047522-0

An D-S, Wang L, Kim MS, Bae H-M, Lee S-T, Im W-T (2011) Solirubrobacter ginsenosidimutans sp. nov., isolated from soil of a ginseng field. Int $\mathrm{J}$ Syst Evol Microbiol 61:2606-2609. https://doi.org/10.1099/ijs.0.028431-0

Benson DA, Karsch-Mizrachi I, Lipman DJ, Ostell J, Wheeler DL (2005) GenBank. Nucleic Acids Res 33:D34-D38. https://doi.org/10.1093/nar/gki063

Brosius J, Palmer ML, Kennedy PJ, Noller HF (1978) Complete nucleotide sequence of a 16S ribosomal RNA gene from Escherichia coli. Proc Natl Acad Sci U S A 75:4801-4805. https://doi.org/10.1073/pnas.75.10.4801

Bull AT, Idris H, Sanderson R, Asenjo J, Andrews B, Goodfellow MM (2018) High altitude, hyper-arid soils of the Central-Andes harbor mega-diverse communities of actinobacteria. Extremophiles 22:47-57. https://doi.org/10. 1007/s00792-017-0976-5

Carreto L, Moore E, Nobre MF, Wait R, Riley PW, Sharp RJ, Da Costa MS (1996) Rubrobacter xylanophilus sp. nov., a new thermophilic species isolated from a thermally polluted effluent. Int J Syst Evol Microbiol 46:460-465. https://doi. org/10.1099/00207713-46-2-460

Chen M-Y, Wu S-H, Lin G-H, Lu C-P, Lin Y-T, Chang W-C, Tsay S-S (2004) Rubrobacter taiwanensis sp. nov., a novel 
thermophilic, radiation-resistant species isolated from hot springs. Int J Syst Evol Microbiol 54:1849-1855. https:// doi.org/10.1099/ijs.0.63109-0

Chen R-W, Wang K-X, Wang F-Z, He Y-Q, Long L-J, Tian X-P (2018) Rubrobacter indicoceani sp. nov., a new marine actinobacterium isolated from Indian Ocean sediment. Int $\mathbf{J}$ Syst Evol Microbiol 68:3487-3493. https://doi.org/10. 1099/ijsem.0.003018

Cole JR, Wang Q, Fish JA, Chai B, McGarrell DM, Sun Y, Brown CT et al (2014) Ribosomal database project: data and tools for high throughput rRNA analysis. Nucleic Acids Res 42:D633-D642. https://doi.org/10.1093/nar/ gkt1244

Connon SA, Lester ED, Shafaat HS, Obenhuber DC, Ponce A (2007) Bacterial diversity in hyperarid Atacama Desert soils. J Geophys Res Biogeosci. https://doi.org/10.1029/ 2006JG000311

Crits-Christoph A, Robinson CK, Barnum T, Fricke WF, Davila AF, Jedynak B, McKay CP et al (2013) Colonization patterns of soil microbial communities in the Atacama Desert. Microbiome 1:28. https://doi.org/10.1186/2049-2618-1-28

de la Torre JR, Goebel BM, Friedmann EI, Pace NR (2003) Microbial diversity of cryptoendolithic communities from the McMurdo dry valleys, Antarctica. Appl Environ Microbiol 69:3858. https://doi.org/10.1128/AEM.69.7. 3858-3867.2003

DiRuggiero J, Wierzchos J, Robinson CK, Souterre T, Ravel J, Artieda O, Souza-Egipsy V et al (2013) Microbial colonisation of chasmoendolithic habitats in the hyper-arid zone of the Atacama Desert. Biogeosciences 10:2439-2450. https://doi.org/10.5194/bg-10-2439-2013

Egas C, Barroso C, Froufe HJ, Pacheco J, Albuquerque L, da Costa MS (2014) Complete genome sequence of the radiation-resistant bacterium Rubrobacter radiotolerans RSPS-4. Stand Genomic Sci 9:1062-1075. https://doi.org/ 10.4056/sigs.5661021

Ferreira AC, Nobre MF, Moore E, Rainey FA, Battista JR, da Costa MS (1999) Characterization and radiation resistance of new isolates of Rubrobacter radiotolerans and Rubrobacter xylanophilus. Extremophiles 3:235-238. https://doi.org/10.1007/s007920050121

Foesel BU, Geppert A, Rohde M, Overmann J (2016) Parviterribacter kavangonensis gen. nov., sp. nov. and Parviterribacter multiflagellatus $\mathrm{sp}$. nov., novel members of Parviterribacteraceae fam. nov. within the order Solirubrobacterales, and emended descriptions of the classes Thermoleophilia and Rubrobacteria and their orders and families. Int J Syst Evol Microbiol 66:652-665. https://doi.org/10.1099/ijsem.0.000770

Furlong MA, Singleton DR, Coleman DC, Whitman WB (2002) Molecular and culture-based analyses of prokaryotic communities from an agricultural soil and the burrows and casts of the earthworm Lumbricus rubellus. Appl Environ Microbiol 68:1265-1279. https://doi.org/10.1128/aem.68. 3.1265-1279.2002

Gao B, Gupta RS (2012) Phylogenetic framework and molecular signatures for the main clades of the phylum Actinobacteria. Microbiol Mol Biol Rev 76:66-112. https:// doi.org/10.1128/mmbr.05011-11

Goodfellow M (2012) Phylum XXVI. Actinobacteria phyla. nov. In: Goodfellow M, Kämpfer P, Busse H-J, Trujillo
ME, Suzuki K, Ludwig W, Whitman WB (eds) Bergey's manual of systematic of bacteriology. The Actinobacteria, part A, vol 5, 2nd edn. Springer, New York, pp 83-84. https://doi.org/10.1002/9781118960608.cbm00004

Goodfellow M, Nouioui I, Sanderson R, Xie F, Bull AT (2018) Rare taxa and dark microbial matter: novel bioactive actinobacteria abound in Atacama Desert soils. Antonie Van Leeuwenhoek 111:1315-1332. https://doi.org/10. 1007/s10482-018-1088-7

Gremion F, Chatzinotas A, Harms H (2003) Comparative 16S rDNA and 16S rRNA sequence analysis indicates that Actinobacteria might be a dominant part of the metabolically active bacteria in heavy metal-contaminated bulk and rhizosphere soil. Environ Microbiol 5:896-907. https://doi. org/10.1046/j.1462-2920.2003.00484.x

Holmes AJ, Bowyer J, Holley MP, O’Donoghue M, Montgomery M, Gillings MR (2000) Diverse, yet-to-be-cultured members of the Rubrobacter subdivision of the Actinobacteria are widespread in Australian arid soils. FEMS Microbiol Ecol 33:111-120. https://doi.org/10.1111/j. 1574-6941.2000.tb00733.x

Idris H, Goodfellow M, Sandeson R, Asenjo JA, Bull AT (2017) Actinobacterial rare biosphere and dark matter revealed in habitats of the Atacama Desert. Sci Rep 7:8373. https://doi. org/10.1038/s41598-017-08937-4

Imperi F, Caneva G, Cancellieri L, Ricci MA, Sodo A, Visca P (2007) The bacterial aetiology of rosy discoloration of ancient wall paintings. Environ Microbiol 9:2894-2902. https://doi.org/10.1111/j.1462-2920.2007.01393.x

Janssen PH (2006) Identifying the dominant soil bacterial taxa in libraries of $16 \mathrm{~S}$ rRNA and 16S rRNA genes. J Appl Environ Microbiol 72:1719-1728. https://doi.org/10.1128/ AEM.72.3.1719-1728.2006

Janssen PH, Yates PS, Grinton BE, Taylor PM, Sait M (2002) Improved culturability of soil bacteria and isolation in pure culture of novel members of the divisions Acidobacteria, Actinobacteria, Proteobacteria, and Verrucomicrobia. Appl Environ Microbiol 68:2391-2396. https://doi.org/10. 1128/aem.68.5.2391-2396.2002

Jurado V, Miller AZ, Alias-Villegas C, Laiz L, Saiz-Jimenez C (2012) Rubrobacter bracarensis sp. nov., a novel member of the genus Rubrobacter isolated from a biodeteriorated monument. Syst Appl Microbiol 35:306-309. https://doi. org/10.1016/j.syapm.2012.04.007

Kämpfer P, Glaeser SP, Busse H-J, Abdelmohsen UR, Hentschel U (2014) Rubrobacter aplysinae sp. nov., isolated from the marine sponge Aplysina aerophoba. Int J Syst Evol Microbiol 64:705-709. https://doi.org/10.1099/ijs.0. 055152-0

Kieser T, Bibb MJ, Buttner MJ, Chater KF, Hopwood DA (2000) Practical Streptomyces genetics. John Innes Foundation, Norwich

Kim MK, Na J-R, Lee T-H, Im W-T, Soung N-K, Yang D-C (2007) Solirubrobacter soli sp. nov., isolated from soil of a ginseng field. Int J Syst Evol Microbiol 57:1453-1455. https://doi.org/10.1099/ijs.0.64715-0

Kim KK, Lee KC, Lee J-S (2012) Patulibacter ginsengiterrae sp. nov., isolated from soil of a ginseng field, and an emended description of the genus Patulibacter. Int J Syst Evol Microbiol 62:563-568. https://doi.org/10.1099/ijs.0. 032052-0 
Lane DJ (1991) 16S/23S rRNA sequencing. In: Stackebrandt E, Goodfellow M (eds) Nucleic acid techniques in bacterial systematics. Wiley, New York, pp 115-175

Ludwig W, Euzéby J, Schumann P, Busse H-J, Trujillo ME, Kämpfer P, Whitman WB (2012) Road map of the phylum Actinobacteria. In: Goodfellow M, Kämpfer P, Busse H-J, Trujillo ME, Suzuki J-I, Ludwig W, Whitman WB (eds) Bergey's manual of systematic bacteriology. The Actinobacteria, part A, vol 5, 2nd edn. Springer, New York, pp 1-28. https://doi.org/10.1002/9781118960608. fbm00052

McCaig AE, Glover LA, Prosser JI (1999) Molecular analysis of bacterial community structure and diversity in unimproved and improved upland grass pastures. Appl Environ Microbiol 65:1721-1730

Meier-Kolthoff JP, Auch AF, Klenk H-P, Göker M (2013) Genome sequence-based species delimitation with confidence intervals and improved distance functions. BMC Bioinformatics 14:60. https://doi.org/10.1186/1471-210514-60

Moffett BF, Nicholson FA, Uwakwe NC, Chambers BJ, Harris JA, Hill TC (2003) Zinc contamination decreases the bacterial diversity of agricultural soil. FEMS Microbiol Ecol 43:13-19. https://doi.org/10.1111/j.1574-6941.2003. tb01041.x

Monciardini P, Cavaletti L, Schumann P, Rohde M, Donadio S (2003) Conexibacter woesei gen. nov., sp. nov., a novel representative of a deep evolutionary line of descent within the class Actinobacteria. Int J Syst Evol Microbiol 53:569-576. https://doi.org/10.1099/ijs.0.02400-0

Neilson JW, Quade J, Ortiz M, Nelson WM, Legatzki A, Tian F, LaComb M et al (2012) Life at the hyperarid margin: novel bacterial diversity in arid soils of the Atacama Desert, Chile. Extremophiles 16:553-566. https://doi.org/10.1007/ s00792-012-0454-z

Norman JS, King GM, Friesen ML (2017) Rubrobacter spartanus sp. nov., a moderately thermophilic oligotrophic bacterium isolated from volcanic soil. Int J Syst Evol Microbiol 67:3597-3602. https://doi.org/10.1099/ijsem.0. 002175

Rainey FA, Ward-Rainey NL, Stackebrandt E (1997) Proposal for a new hierarchic classification system, Actinobacteria classis nov. In: Stackebrandt E, Rainey FA, Ward-Rainey NL (eds) Int J Syst Evol Microbiol. vol 47, pp 479-491. https://doi.org/10.1099/00207713-47-2-479

Reddy GSN, Garcia-Pichel F (2009) Description of Patulibacter americanus sp. nov., isolated from biological soil crusts, emended description of the genus Patulibacter Takahashi et al. 2006 and proposal of Solirubrobacterales ord. nov. and Thermoleophilales ord. nov. Int J Syst Evol Microbiol 59:87-94. https://doi.org/10.1099/ijs.0.64185-0

Rheims H, Spröer C, Rainey FA, Stackebrandt E (1996) Molecular biological evidence for the occurrence of uncultured members of the actinomycete line of descent in different environments and geographical locations. Microbiology 142(10):2863-2870. https://doi.org/10. 1099/13500872-142-10-2863

Sait M, Hugenholtz P, Janssen PH (2002) Cultivation of globally distributed soil bacteria from phylogenetic lineages previously only detected in cultivation-independent surveys.
Environ Microbiol 4:654-666. https://doi.org/10.1046/j. 1462-2920.2002.00352.x

Saul DJ, Aislabie JM, Brown CE, Harris L, Foght JM (2005) Hydrocarbon contamination changes the bacterial diversity of soil from around Scott Base, Antarctica. FEMS Microbiol Ecol 53:141-155. https://doi.org/10.1016/j.femsec. 2004.11.007

Schabereiter-Gurtner C, Piñar G, Vybiral D, Lubitz W, Rölleke S (2001) Rubrobacter-related bacteria associated with rosy discolouration of masonry and lime wall paintings. Arch Microbiol 176:347-354. https://doi.org/10.1007/ s002030100333

Seki T, Matsumoto A, Shimada R, Inahashi Y, Ōmura S, Takahashi Y (2012) Conexibacter arvalis sp. nov., isolated from a cultivated field soil sample. Int J Syst Evol Microbiol 62:2400-2404. https://doi.org/10.1099/ijs.0.036095-0

Sievers F, Wilm A, Dineen D, Gibson TJ, Karplus K, Li W, Lopez R et al (2011) Fast, scalable generation of highquality protein multiple sequence alignments using Clustal Omega. Mol Syst Biol 7:539. https://doi.org/10.1038/msb. 2011.75

Singleton DR, Furlong MA, Peacock AD, White DC, Coleman DC, Whitman WB (2003) Solirubrobacter pauli gen. nov., sp. nov., a mesophilic bacterium within the Rubrobacteridae related to common soil clones. Int J Syst Evol Microbiol 53:485-490. https://doi.org/10.1099/ijs.0. 02438-0

Stach JE, Maldonado LA, Masson DG, Ward AC, Goodfellow M, Bull AT (2003) Statistical approaches for estimating actinobacterial diversity in marine sediments. Appl Environ Microbiol 69:6189-6200. https://doi.org/10.1128/aem. 69.10.6189-6200.2003

Stackebrandt E (2005) Validation of publication of new names and new combinations previously effectively published outside the IJSEM. List no. 102. Int J Syst Evol Microbiol 55:547-549. https://doi.org/10.1099/ijs.0.63680-0

Staden R, Beal KF, Bonfield JK (2000) The Staden package, 1998. Methods Mol Biol 132:115-130. https://doi.org/10. 1385/1-59259-192-2:115

Suzuki K (2012a) Rubrobacteria class. nov. In: Goodfellow M, Kämpfer P, Busse H-J, Trujillo ME, Suzuki J-I, Ludwig W, Whitman WB (eds) Bergey's manual of systematic bacteriology. The Actinobacteria, part B, vol 5, 2nd edn. Springer, New York, pp 2004-2009

Suzuki K (2012b) Rubrobacter Suzuki, Collins, Iijima and Komagata 1989, 93 ${ }^{\mathrm{VP}}$ (Effective publication: Suzuki, Collins, Iijima and Komagata 1988, 38.). In: Goodfellow M, Kämpfer P, Busse H-J, Trujillo ME, Suzuki J-I, Ludwig W, Whitman WB (eds) Bergey's manual of systematic bacteriology. The Actinobacteria, part B, vol 5, 2nd edn. Springer, New York, pp 2006-2009

Suzuki K, Whitman WB (2012) Class VI. Thermoleophilia class. nov. In: Goodfellow M, Kämpfer P, Busse H-J, Trujillo ME, Suzuki J-I, Ludwig W, Whitman WB (eds) Bergey's manual of systematic bacteriology. The Actinobacteria, part B, vol 5, 2nd edn. Springer, New York, pp 2010-2028

Suzuki K-i, Collins MD, Iijima E, Komagata K (1988) Chemotaxonomic characterization of a radiotolerant bacterium, Arthrobacter radiotolerans: Description of Rubrobacter radiotolerans gen. nov., comb. nov. FEMS 
Microbiol Lett 52:33-39. https://doi.org/10.1111/j.15746968.1988.tb02568.x

Takahashi Y, Matsumoto A, Morisaki K, Ōmura S (2006) Patulibacter minatonensis gen. nov., sp. nov., a novel actinobacterium isolated using an agar medium supplemented with superoxide dismutase, and proposal of Patulibacteraceae fam. nov. Int J Syst Evol Microbiol 56:401-406. https://doi.org/10.1099/ijs.0.63796-0

Waterhouse AM, Procter JB, Martin DM, Clamp M, Barton GJ (2009) Jalview version 2-a multiple sequence alignment editor and analysis workbench. Bioinformatics 25:1189-1191. https://doi.org/10.1093/bioinformatics/ btp033

Wei L, Ouyang S, Wang Y, Shen X, Zhang L (2014) Solirubrobacter phytolaccae sp. nov., an endophytic bacterium isolated from roots of Phytolacca acinosa Roxb. Int J Syst Evol Microbiol 64:858-862. https://doi.org/10.1099/ ijs.0.057554-0

Yarza P, Yilmaz P, Pruesse E, Glöckner FO, Ludwig W, Schleifer KH, Whitman WB et al (2014) Uniting the classification of cultured and uncultured bacteria and archaea using 16S rRNA gene sequences. Nat Rev Microbiol 12:635-645. https://doi.org/10.1038/nrmicro3330

Ye J, Coulouris G, Zaretskaya I, Cutcutache I, Rozen S, Madden TL (2012) Primer-BLAST: a tool to design target-specific primers for polymerase chain reaction. BMC Bioinformatics 13:134. https://doi.org/10.1186/1471-2105-13-134

Yoon SH, Ha SM, Kwon S, Lim J, Kim Y, Seo H, Chun J (2017) Introducing EzBioCloud: a taxonomically united database of $16 \mathrm{~S}$ rRNA gene sequences and whole-genome assemblies. Int J Syst Evol Microbiol 67:1613-1617. https://doi.org/10.1099/ijsem.0.001755

Yoshinaka T, Yano K, Yamaguchi H (1973) Isolation of highly radioresistant bacterium, Arthrobacter radiotolerans nov. sp. Agric Biol Chem 37:2269-2275. https://doi.org/10. 1080/00021369.1973.10861003

Zarilla KA, Perry JJ (1984) Thermoleophilum album gen. nov. and sp. nov., a bacterium obligate for thermophily and $n$ alkane substrates. Arch Microbiol 137:286-290. https:// doi.org/10.1007/bf00410723

Zarilla KA, Perry JJ (1986) Deoxyribonucleic acid homology and other comparisons among obligately thermophilic hydrocarbonoclastic bacteria, with a proposal for Thermoleophilum minutum sp. nov. Int J Syst Evol Microbiol 36:13-16. https://doi.org/10.1099/00207713-36-1-13

Zhang L, Zhu L, Si M, Li C, Zhao L, Wei Y, Shen X (2014) Solirubrobacter taibaiensis sp. nov., isolated from a stem of Phytolacca acinosa Roxb. Antonie Van Leeuwenhoek 106:279-285. https://doi.org/10.1007/s10482-014-0194-4

Zhi X-Y, Li W-J, Stackebrandt E (2009) An update of the structure and $16 \mathrm{~S}$ rRNA gene sequence-based definition of higher ranks of the class Actinobacteria, with the proposal of two new suborders and four new families and emended descriptions of the existing higher taxa. Int J Syst Evol Microbiol 59:589-608. https://doi.org/10.1099/ijs.0. 65780-0

Publisher's Note Springer Nature remains neutral with regard to jurisdictional claims in published maps and institutional affiliations. 